EGU21-13369, updated on 02 Aug 2021

https://doi.org/10.5194/egusphere-egu21-13369

EGU General Assembly 2021

(C) Author(s) 2021. This work is distributed under

the Creative Commons Attribution 4.0 License.

\title{
No-regret adaptation to climate change through management of glacial lakes in the Santa River Basin in Peru
}

\author{
Gladis Celmi ${ }^{1}$, Andrea Momblanch ${ }^{2}$, Tim Hess ${ }^{2}$, Catriona L. Fyffe ${ }^{3}$, Emily Potter ${ }^{4}$, Andrew Orr ${ }^{6}$, \\ Fabian Drenkhan ${ }^{5}$, Noah Walker-Crawford ${ }^{5}$, Edwin Loarte ${ }^{1}$, Maria Gracia Bustamante ${ }^{1}$, and \\ Francesca Pellicciotti ${ }^{3}$ \\ ${ }^{1}$ Instituto Nacional de Investigación en Glaciares y Ecosistemas de Montaña, Peru (gcelmi@inaigem.gob.pe) \\ ${ }^{2}$ Cranfield University, UK \\ ${ }^{3}$ University of Northumbria, UK \\ ${ }^{4}$ University of Leeds, UK \\ ${ }^{5}$ Pontificia Universidad Católica del Perú \\ ${ }^{6}$ British Antarctic Survey, UK
}

The vast majority ( 70\%) of tropical glaciers in the world are located in the Peruvian Andes. The Santa River Basin, in the Ancash region of Peru, is bound by two parallel mountain ranges; the Cordillera Blanca to the east and the Cordillera Negra to the west. The main water sources in the Cordillera Blanca are rivers and lakes originated from glacier melt, while the Cordillera Negra has no glaciers and depends on seasonal rainfall. In the last decades, water resources have decreased due to climate change, while demand has increased due to population growth and intensification of agricultural and industrial activities. Moreover, higher water levels in glacial lakes due to accelerated glacier melt has reduced their flood attenuation capacity that, along with other triggers of outburst floods, can have catastrophic consequences. One of the strategies adopted by the regional government is the construction of dams, floodgates and siphon drainage systems to reduce the risk of outburst floods. The lowering of lake water levels to provide flood attenuation conflicts with the need for increasing water regulation in the basin (to compensate glacier mass loss) and alters the natural downstream flow regime.

This study responds to the need for long-term planning of the major glacial lakes in the Santa River Basin to satisfy all water uses, including environmental ones, and contributing to flood reduction under alternative future climate change scenarios. We adopt a systems analysis approach with the support of the Water Evaluation and Planning system (WEAP) coupled with the hydro-glaciological model TOPographic Kinematic APproximation and Integration (TOPKAPI). They are driven by high-resolution climate projections from the Weather Research and Forecast (WRF) model for future emission scenarios and global climate models available in the CMIP5, for the period 2022-2050. The integration of these models allows representing the complex hydrology of the catchment, explicitly accounting for glacier mass change, and water resources management including the main lakes and water demands. A large spectrum of climate change and lake management scenarios are analysed with a no-regret approach using criteria related to the 
reliability of water supply for human demands and environmental flows, along with flood abatement and water scarcity. The results of this study that interface hydrology, water demands and infrastructures support local decision-making and exchange with stakeholders in the Santa River Basin, which will strengthen water security across water uses, fostering development and economic growth in the region. 